\title{
An Alginate Lyase from Azotobacter vinelandii Phage
}

\author{
By I. W. DAVIDSON, ${ }^{*}$ C. J. LAWSON $\dagger$ AND I. W. SUTHERLAND \\ Department of Microbiology, University of Edinburgh, \\ West Mains Road, Edinburgh EH9 $3 \mathrm{JG}$ \\ and \\ $\uparrow$ Philip Lyle Memorial Laboratory, Tate \& Lyle Ltd, P.O. Box 68, \\ Reading, Berkshire
}

(Received I6 June 1976; revised 8 August 1976)

SUMMAR Y

The alginate depolymerase associated with bacteriophage infection of Azotobacter vinelandii has been used in the analysis of sodium alginate. The enzyme degraded the polysaccharide to a series of oligouronides each containing a terminal 4-deoxy- $\alpha$-L-erythro-hex-4-enopyranuronosyl residue. Analysis of these oligouronides, together with kinetic information, indicated that the enzyme was specific for mannuronic acid-containing regions of the polyuronide. The specificity of the enzyme made it possible to determine the primary structure of the macromolecule.

The phage-induced enzyme was shown to be distinct from the alginate lyase elaborated by the host organisms by its $\mathrm{pH}$ optimum, molecular weight, Michaelis constant and stability.

\section{INTRODUCTION}

The production of enzyme active against capsular polysaccharides is a feature of bacteriophages which infect encapsulated bacteria. A number of such systems have been studied and phage-bound and soluble forms of the same enzyme have been recognized (e.g. Sutherland, 1967, 1972; Thurow, Niemann \& Stirm, 1975). Several phages which infect strains of Azotobacter vinelandii have been described (Duff \& Wyss, I 961; Pike \& Wyss, 1975). Infection of capsulate strains yielded plaques surrounded by 'craters' - areas of viable decapsulated bacteria. Eklund \& Wyss (1962) described a capsule-digesting enzyme which was recovered from cultures of phage-infected $A$. vinelandii. Although the enzyme caused a rapid drop in the viscosity of capsular polysaccharide solutions, the mechanism of depolymerization was not investigated.

Gorin \& Spencer (1966) and later Haug \& Larsen (197I) demonstrated that the exopolysaccharide of $A$. vinelandii was similar in most respects to the algal polysaccharide, alginic acid. Both were linear block copolymers composed of D-mannuronic acid and L-guluronic acid; in addition, the bacterial polymer was $O$-acetylated. Enzymes degrading algal alginate have been described (Preiss \& Ashwell, 1962; Nisizawa, Fujibayashi \& Kashiwabara, I968), such preparations being of both bacterial and non-bacterial origin. As we are currently studying aspects of bacterial alginate structure and synthesis (Davidson \& Sutherland, 1975; Pindar \& Bucke, 1975), the enzyme associated with phage-infection of $A$. vinelandii, together with enzymes from other sources, provided a useful and convenient source of alginate depolymerase. The present paper reports on the specificity and mode of action of this enzyme.

* Present address: Microbiological Research Establishment, Porton, Salisbury, Wiltshire. 


\section{METHODS}

Bacteria and bacteriophage. The Azotobacter vinelandii strain used in this study was kindly provided by Professor O. Wyss (University of Texas). Other strains of the same bacteria, isolated locally, were also used as sources of polysaccharide and as possible bacteriophage hosts. The bacteria were grown and maintained on Burk's nitrogen-free medium (Duff \& Wyss, I96I). A bacteriophage apparently specific for the Wyss strain and inactive against a number of other $A$. vinelandii strains was isolated from soil by standard techniques. It formed cratered plaques similar to those described by Eklund \& Wyss (1962). Phage stocks were prepared by the semi-solid agar technique and maintained at $4{ }^{\circ} \mathrm{C}$.

Enzyme preparation. Enzyme was prepared from phage-infected cultures (5 l) of A. vinelandii using the sloppy agar overlay procedure described by Clowes \& Hayes (I968). After $24 \mathrm{~h}$ incubation at $30^{\circ} \mathrm{C}$, the agar was removed from the fluid by low speed centrifugation. Phage particles were deposited by centrifuging at $45000 \mathrm{~g}$ for $2.5 \mathrm{~h}$ leaving the crude enzyme solution in the supernatant fluid. Partial purification of the enzyme was achieved by fractionation on a column $(55 \times 2 \mathrm{~cm})$ of Sephadex Groo eluted with 0.0I M-Mops/NaOH buffer, $\mathrm{pH} 7 \cdot 5$ [Mops, 3-( $N$-morpholino)propanesulphonic acid]. Fractions having alginase activity were obtained as a single peak of activity, pooled and stored at $-20{ }^{\circ} \mathrm{C}$. This procedure increased the specific activity from 3.5 to $18 \cdot 6$. Bacteria and phage particles were absent.

Determination of enzymic activity. The yield of unsaturated material from lyase action was determined by the periodate-thiobarbituric acid (TBA) procedure of Weissbach \& Hurwitz (1959). One unit of enzyme activity was defined as the amount of enzyme required to liberate the equivalent of I $\mu \mathrm{mol} \beta$-formylpyruvate $\min ^{-1}: 0.0 \mathrm{I} \mu \mathrm{mol} \beta$-formylpyruvate produced an extinction of 0.29 at $549 \mathrm{~nm}$ (Preiss \& Ashwell, 1962).

Analytical procedures. Protein was determined by the method of Lowry et al. (195I), using bovine serum albumin as standard. Total carbohydrate was estimated by the phenol/ sulphuric acid reaction of Dubois et al. (1956).

Preparation and analysis of substrates. Algal alginates were obtained from various commercial sources; bacterial alginate from sucrose-grown $A$. vinelandii was obtained as described by Pindar \& Bucke (1975). Alginates were partially purified using the procedure of Bucke (1974). Ratios of mannuronic acid to guluronic acid were determined by total acid hydrolysis of the polysaccharide using a method modified from that of Haug (I964), involving hydrolysis and high voltage paper electrophoresis (C. J. Lawson \& K. E. Rudland, unpublished results). Homopolymeric substrates (polymannuronic or polyguluronic acids) were prepared by partial acid hydrolysis of alginic acid as described by Penman \& Sanderson (1972). The identity of the preparations was confirmed by n.m.r. spectroscopy.

Enzymic hydrolysis of alginates. Alginate samples $(50 \mathrm{mg})$ dissolved in Io mM-Mops/ $\mathrm{NaOH}$ buffer were hydrolysed with sufficient alginate lyase to give maximal hydrolysis in $20 \mathrm{~h}$ at $30{ }^{\circ} \mathrm{C}$. Microbial growth was inhibited by the addition of toluene. $K_{\mathrm{m}}$ and $V_{\max }$ were determined by the method of Lineweaver \& Burk (I934).

Paper chromatography and electrophoresis. Paper chromatography (descending) was performed routinely on Whatman no. I paper; Whatman 3 MM paper was used for preparative work. The solvent systems were: A, ethyl acetate/pyridine/acetic acid/water $(5: 5: 1: 3$, by vol.); B, ethyl acetate/acetic acid/formic acid/water (I8:3:I:4, by vol.); C, butan-I-ol/ acetic acid/water (50:12:25, by vol.). Irrigation times were 24,24 and $48 \mathrm{~h}$ respectively. Paper electrophoresis was performed on Whatman no. I paper in pyridinium acetate buffer $\mathrm{pH} 5.3$ using a current of 80 to $100 \mathrm{~mA}$ at $3.5 \mathrm{kV}$ for $\mathrm{I} .5 \mathrm{~h}$ on a Locarte (London) equipment 
with $75 \times 20 \mathrm{~cm}$ cooled plate area. Monosaccharides and oligosaccharides were detected with alkaline silver nitrate (Trevelyan, Procter \& Harrison, 1950) or with the periodatesodium thiobarbiturate reagent (Warren, 1960).

Partial characterization of products of alginase activity. Oligouronides released from solutions of sodium alginate by the action of the lyase were fractionated on a column $(38 \times 1 \cdot 2 \mathrm{~cm})$ of Sephadex Gi5, using pyridinium acetate buffer $\mathrm{pH} 5 \cdot 3$ as eluant. Unsaturated oligouronides were also isolated by preparative paper chromatography (solvent $\mathrm{B}$ ), and checked for chromatographic purity in solvents $\mathrm{A}$ and $\mathrm{B}$. After hydrolysis with $2 \mathrm{M}-\mathrm{HCl}$ for $2 \mathrm{~h}$ at $100{ }^{\circ} \mathrm{C}$, the acid was removed by evaporation in the presence of $\mathrm{NaOH}$. A small volume of water was added and the process was repeated. The hydrolysis products were examined by paper chromatography (solvent $\mathrm{C}$ ) and high voltage electrophoresis. Papers were developed with alkaline silver nitrate and the composition of each oligosaccharide was estimated from the relative intensity of the stained area. Separation of the oligouronides on a column of Sephadex Gi5 with monosaccharide, disaccharide and trisaccharide markers was used to assist determination of the degree of polymerization.

Disc gel electrophoresis. Polyacrylamide gel electrophoresis (P.A.G.E.) of proteins was performed using the method of Weber \& Osborn (1969).

\section{RESULTS}

Properties of phage and enzyme

The phage isolated using the $A$. vinelandii Wyss strain as host was specific for this strain and did not lyse a number of other $A$. vinelandii strains tested nor did it lyse several other Azotobacter species. The enzyme recovered from phage-infected bacterial cultures, and prepared as described in the Methods, produced a series of fragments when incubated with alginate. These oligouronides were positive in the thiobarbituric acid test and absorbed strongly at $232 \mathrm{~nm}$ in aqueous solution, indicating that the enzyme was of the lyase type (EC. $4 \cdot 2.2 .3$ ). Tests showed that it was active in the $\mathrm{pH}$ range $7 \cdot 0$ to 8.5 with maximal activity at $\mathrm{pH} 7 \cdot 7$.

\section{Molecular weight}

The molecular weight of the enzyme, determined by comparing the electrophoretic mobility of the lyase with the mobilities of standard marker proteins, was in the region of 30000 to 35000 . Pike \& Wyss (1975) determined the molecular weight of Azoto-phage A3 I alginate depolymerase to be in the range 35000 to 42000 .

\section{Specificity of phage-induced lyase}

When incubated, under standard conditions, with a series of alginates of different mannuronic acid to guluronic acid ratios, the enzyme released progressively more TBA-positive material from substrates with higher mannuronic acid content (Table I).

The rate of release of TBA-positive material from homopolymeric substrates (polymannuronic acid and polyguluronic acid) prepared from algal alginate is shown in Fig. I. There is clearly considerable activity against the polymannuronic acid and little against the polyguluronic material.

The Michaelis constant for the enzyme varied according to the nature of the alginate sample used as substrate. The results indicated that the bacteriophage lyase was specific for mannuronic acid-containing regions of the polysaccharide. When Michaelis constants were corrected to take account of the variable amount of mannuronic acid in the substrate, i.e. 
Table I. Rate of release of unsaturated uronic acid from a series of alginates

The enzyme was tested under standard conditions (0.05 M-Mops/ $\mathrm{NaOH}$ buffer, $\mathrm{pH} 7.5$, at $30^{\circ} \mathrm{C}$ ) for the release of thiobarbituric acid (TBA) positive material from alginates of differing composition. $K_{\mathrm{m}}$ values were calculated on the basis of total alginate and of polymeric mannuronic acid available in each substrate tested.

\begin{tabular}{|c|c|c|c|c|}
\hline \multicolumn{2}{|c|}{ Alginate } & \multirow[b]{2}{*}{$\begin{array}{l}\text { TBA test } \\
\left(E_{549} \mathrm{~h}^{-1}\right)\end{array}$} & \multicolumn{2}{|c|}{$\overbrace{\mathrm{m}}$} \\
\hline Source & $\begin{array}{c}\text { Mannuronic acid } \\
(\%)\end{array}$ & & $\mathrm{mg}$ polymer $\mathrm{ml}^{-1}$ & $\begin{array}{l}\text { Mannuronic acid } \\
(\mathrm{mM})\end{array}$ \\
\hline Bacterial & $26 \cdot 5$ & 0.084 & 715 & $I \cdot 05$ \\
\hline Algal & $31 \cdot 5$ & O.IIO & 530 & 0.94 \\
\hline Algal & $48 \cdot 0$ & 0.185 & - & - \\
\hline Algal & 48.0 & 0.200 & 470 & $\mathrm{I} \cdot 28$ \\
\hline Bacterial & $55^{\circ} 0$ & 0.240 & 350 & I. 09 \\
\hline
\end{tabular}

-, Not measured.

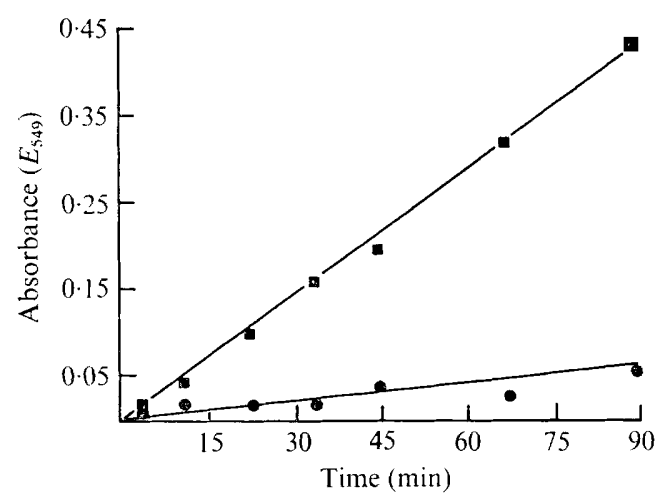

Fig. I

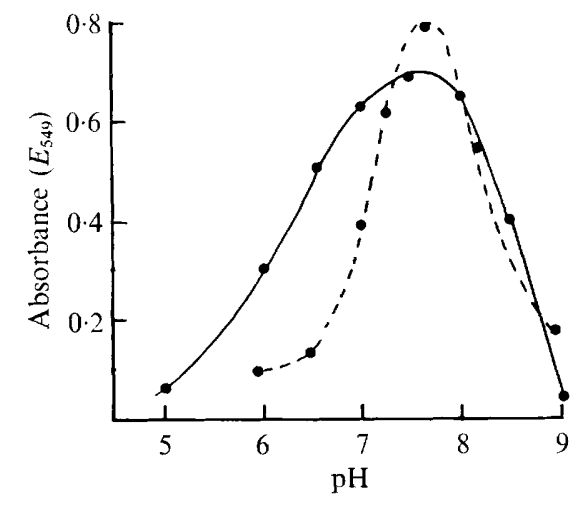

Fig. 2

Fig. I. Release of thiobarbituric acid positive material from polymannuronic acid ( $\mathbf{\square}$ ) and polyguluronic acid (O) by $A$. vinelandii bacteriophage lyase. Homopolymeric substrates were prepared as described in Methods and treated with the bacteriophage-induced lyase in $0.05 \mathrm{M}-\mathrm{Mops} /$ $\mathrm{NaOH}$ buffer, $\mathrm{pH} 7.5$, at $30^{\circ} \mathrm{C}$. Samples from the incubation mixture were withdrawn and tested with the thiobarbituric acid reagent.

Fig. 2. Effect of $\mathrm{pH}$ on $A$. vinelandii endogenous lyase (-) and $A$. vinelandii bacteriophage lyase (- - ). Samples of alginate of relatively high mannuronic acid content were used as substrate and mixed with either of the enzymes under test in $0.05 \mathrm{M}$ buffer of the desired $\mathrm{pH}$ value (Mops or Tris were used to cover the range). After incubation at $30^{\circ} \mathrm{C}$ for $2 \mathrm{~h}$ the amount of thiobarbituric acid positive material was measured.

Michaelis constants were calculated from the available mannuronic acid rather than total alginate, a reproducible constant was obtained (Table I).

As an endogenous alginate lyase could be recovered from cultures of $A$. vinelandii, an observation also made by Haug \& Larsen (I97I), it was necessary to confirm that the phage enzyme was the product of phage genes. Thus, enzyme prepared as described by Haug \& Larsen (197I) was compared with the phage enzyme.

The enzyme preparations differed markedly in $\mathrm{pH}$-activity profiles, kinetic constant, molecular weight and stability. The effect of $\mathrm{pH}$ on the activity of the two enzymes is illustrated in Fig. 2. The Michaelis constants for the bacterial and phage enzymes were 
Table 2. Chromatographic mobilites of products of bacteriophage alginate lyase activity

\begin{tabular}{lcccc} 
Oligouronide & \multicolumn{3}{c}{$R_{\text {GulA }}$} & Component sugars detected* \\
Solvent A & Solvent B & +++ & GulA \\
0.71 & 0.99 & - & + \\
0.63 & 0.56 & +++ & - \\
Trimer & 0.37 & 0.26 & +++ & - \\
Tetramer & 0.32 & 0.14 & ++ & + \\
Pentamer & 0.16 & 1.07 &. &. \\
Mannuronic acid & 1.28 & &
\end{tabular}

GulA, guluronic acid; ManA, mannuronic acid.

* Oligosaccharides yielding a single spot in both solvents and on paper electrophoresis were hydrolysed in $2 \mathrm{M}-\mathrm{HCl}$ and the products were examined in solvent $\mathrm{C} .+++,++,+,-$, indicate relative yields of the component uronic acids.

calculated to be 9 ro and $5 \mathrm{IO} \mathrm{mg} \mathrm{ml}^{-1}$ respectively (using a bacterial alginate preparation as substrate). The molecular weight of the phage enzyme was estimated to be in the region of 30000 to 35000 . Fractionation of the crude bacterial preparation in a column of Sephadex G50 resulted in exclusion of the enzymic activity from the filtration gel, indicating a molecular weight of greater than 50000 . The bacterial enzyme rapidly lost its catalytic activity when stored at $-20{ }^{\circ} \mathrm{C}$, whereas the bacteriophage lyase remained active even after 3 months storage.

\section{Preliminary characterization of unsaturated oligouronides}

The products released from an algal alginate by the action of bacteriophage lyase were examined by paper chromatography. All compounds were visualized by spraying the paper with periodate-sodium thiobarbiturate, and no additional compounds were detected when papers were developed with alkaline silver nitrate. Thus silver nitrate positive fragments contained an unsaturated monosaccharide residue. Fractionation of the products from a column of Sephadex Gi5 indicated that the two fastest moving sugars (on paper, solvent A) both had degrees of polymerization of two. Each of the oligouronides released by lyase action was isolated and purified by preparative paper chromatography (solvent A), and shown to be chromatographically pure, before acid hydrolysis. The chromatographic mobilities of the oligouronides relative to guluronic acid are shown in Table 2.

\section{DISCUSSION}

The aim of this study was to investigate the possible use of alginate depolymerase in the routine analysis of the polysaccharide. The results of kinetic studies reported here indicate that the specific nature of the phage enzyme makes it possible to estimate the percentage of mannuronic acid within the polyuronide (Table I). That the enzyme was specific for mannuronic acid-containing regions of the polymer [and thus may be designated a poly (I,4- $\beta$-Dmannuronide) lyase, EC. 4.2.2.3] was confirmed by analysis of the products of the lyase activity. Although the unsaturated diuronide, 4-O-(4-deoxy- $\alpha$-L-erythro-hex-4-enopyranuronosyl)-D-mannuronic acid $(\Delta-\mathrm{ManA})$, could have arisen from either homopolymeric mannuronic acid blocks or alternating sequences (as indicated below), mannuronosyl oligouronides with a degree of polymerization greater than two could have arisen only from mannuronic acid blocks. The 4- $O$-(4-deoxy- $\alpha$-L-erythro-hex-4-enopyranuronosyl)-L-guluronic acid $(\Delta-\mathrm{GulA})$ detected probably arose from the reducing end of the polysaccharide.

$$
-\mathrm{M}-\mathrm{G}-\mathrm{M}-\mathrm{M}-\mathrm{M}-\mathrm{M}-\mathrm{ManA}
$$


The problem in defining the exact specificity of the enzyme is associated with the known non-uniformity of the substrate which contains alternating and homopolymeric regions. The enzyme may be active on both polymannuronic acid regions and alternating portions of the substrate, although showing a specificity for the 4-O-mannuronosyl linkages (as glycone) with elimination of either uronic acid as the aglycone. This would then account for the presence of L-guluronic acid in the pentamer. Some specificity for the degree of polymerization of the substrate may also be present, as attempts to use homopolymeric substrates (of relatively low degree of polymerization, about 10 to 25 ) to determine $K_{\mathrm{m}}$ gave inconsistent results.

Although a number of other alginate lyases have been described, many of these prepara. tions have not been adequately characterized and are therefore of unknown specificity. More recent studies have distinguished between polymannuronate-specific and polyguluronate-specific enzymes. Most of the enzymes have been reported as being polyguluronate lyases (e.g. Kashiwabara, Suzuki \& Nisizawa, 1969) but polymannuronate lyases have been obtained from marine algae including Laminaria sp. (Madgwick, Haug \& Larsen, I973), hepatopancreas of abalone (Nakada \& Sweeney, 1967) and also from the same organ in the marine mollusc, Dolabella auricula (Nisizawa et al., 1968). The enzymes present in the Dolabella preparation degraded mannuronate-rich alginate and polymannuronic acid but were virtually inactive against polyguluronic acid. They thus show considerable similarities in their specificity to the phage enzyme described here. Differences can be seen in the $\mathrm{pH}$ optimum and other properties of the protein.

Although numerous enzymes have been described as components of bacteriophages which infect capsulate bacteria or have been isolated from the phage lysate, most of these have been characterized as polysaccharide hydrolases. An exception was reported from streptococcal phages lysing Streptococcus species that produce hyaluronic acid. Kjems (1958) reported the production of a hyaluronidase by phage-infected streptococci. The enzyme activity was associated with the viral particles and in a soluble form. The bacteriophage-borne enzyme has been isolated and identified as a hyaluronate lyase releasing four oligosaccharides, two of which have been identified as a tetrasaccharide and an octasaccharide with reducing terminals of $N$-acetyl-D-glucosamine (Niemann et al., 1976). The enzyme thus resembles that from Azotobacter phage in producing an unsaturated uronic acid, in this case derived from glucuronic acid.

I.W.D. wishes to thank the Science Research Council and Tate \& Lyle Ltd for a C.A.P.S. studentship.

\section{REFERENCES}

BuCKE, C. (1974). Polyacrylamide gel electrophoresis of alginic acid. Journal of Chromatography 89, 99-102. Clowes, R. C. \& HAYES, W. (1968). Experiments in Microbial Genetics. Oxford: Blackwell Scientific Publications.

Davidson, I. W. \& Sutherland, I.W. (1975). Microbial depolymerization of bacterial alginates. Proceedings of the Society for General Microbiology 2, 77-78.

Dubois, M., Gilles, K. A., Hamilton, J. K., Rebers, P. A. \& Smith, F. (1956). Colorimetric method for determination of sugar and related substances. Analytical Chemistry 28, 350-356.

DuFF, J. T. \& Wyss, O. (I96I). Isolation and classification of a new series of Azotobacter bacteriophages. Journal of General Microbiology 24, 273-289

EKLUND, C. \& WYSS, O. (I962). Enzyme associated with bacteriophage infection. Journal of Bacteriology 84, I209-12I5.

Gorin, P. A. J. \& Spencer. J. F. T. (1966). Exocellular alginic acid from Azotobacter vinelandii. Canadian Journal of Chemistry 44, 993-998. 
HAUG, A. (1964). Composition and Properties of Alginates, Report no. 30. Trondheim, Norway: Norwegian Institute of Seaweed Research.

Haug, A. \& Larsen, B. (I97I). Biosynthesis of alginate. II. Polymannuronic acid C-5 epimerase from Azotobacter vinelandii. Carbohydrate Research 17, 297-308.

Kashiwabara, Y., Suzuki, H. \& Nisizawa, K. (1969). Alginate lyases from Pseudomonads. Journal of Biochemistry 6, 503-512.

KJEMS, E. (1958). Studies on streptococcal bacteriophages. 3. Hyaluronidase produced by the streptococcal phage-host system. Acta pathologica et microbiologica scandinavica 44, 424-439.

LineweAver, H. \& BURK, D. (1934). The determination of enzyme dissociation constants. Journal of the American Chemical Society 56, 658-666.

Lowry, O. H., Rosebrough, N. J., Farr, A. L., \& Randall, R. J. (I95I). Protein measurement with the Folin phenol reagent. Journal of Biological Chemistry 193, 265-275.

Madgwick, J., Haug, A. \& LARSEN, B. (1973). Alginate lyase in the brown alga Laminaria digitata (Huds) Lamour. Acta chemica scandinavica 27, 711 1-712.

Nakada, H. I. \& Sweeney, P. C. (1967). Alginic acid degradation by eliminases from abalone hepatopancreas. Journal of Biological Chemistry 242, 845-85I.

Nifmann, H., Birch-Anderson, A., KJems, E., Mansa, B. \& Stirm, S. (1976). Depolymerization of streptococcal hyaluronic acid by a bacteriophage-borne lyase. Acta pathologica et microbiologica scandinavica B84, I45-I 53 .

Nisizawa, K., Fujibayashi, S. \& Kashiwabara, Y. (I968). Alginate lyases in the hepatopancreas of a marine mollusc, Dolabella auricula Solander. Journal of Biochemistry 64, 25-37.

Penman, A. \& Sanderson, G. (1972). A method for the determination of uronic acid sequence in alginate. Carbohydrate Research 25, 273-282.

PIKE, L. \& WYSS, O. (I975). Isolation and characterization of phage-resistant strains of Azotobacter vinelandii. Journal of General Microbiology 89, 182-186.

Pindar, D. \& Bucke, C. (I975). The biosynthesis of alginic acid by Azotobacter vinelandii. Biochemical Journal 152, 617-622.

Preiss, J. \& Ashwell, G. (Igúz). Alginic acid metabolism in bacteria. I. Enzymatic formation of unsaturated oligosaccharides and 4-deoxy-L-erythro-5-hexose-ulose uronic acid. Journal of Biological Chemistry 237, 309-3I6.

Sutherland, I. W. (I967). Phage-induced fucosidases hydrolysing the exopolysaccharide of Klebsiella aerogenes type 54 (A3 $\left.\mathrm{S}_{\mathrm{I}}\right)$. Biochemical Journal ro4, $278-285$.

Sutherland, 1. W. (1972). The exopolysaccharides of Klebsiella serotype 2 strains as substrates for phageinduced polysaccharide depolymerases. Journal of General Microbiology 7o, 33 I-338.

Thurow, H., Niemann, H. \& Stirm, S. (1975). Bacteriophage-borne enzymes in carbohydrate chemistry. Carbohydrate Research 4I, 257-27I.

Trevelyan, W. E., Procter, D. P. \& Harrison, J. S. (I950). Detection of sugars on paper chromatograms. Nature, London $\mathrm{r66}, 444-445$.

WARREN, L. (1960). Thiobarbituric acid spray reagent for deoxy sugars and sialic acids. Nature, London $\mathbf{1 8 6}$, 237.

Weber, K. \& Osborn, M. (1969). The reliability of molecular weight determinations by dodecyl-sulphatepolyacrylamide gel electrophoresis. Journal of Biological Chemistry 244, 4406-44I 2.

Weissbach, A. \& Hurwitz, J. (I959). The formation of 2-keto-3-deoxyheptonic acid in extracts of Escherichia coli B. Journal of Biological Chemistry 234, 705-709. 